\title{
MENGKAJI PERTUMBUHAN BIOMASSA DAN BAKTERI PADA PROSES PEMBUATAN BIOGAS DARI LIMBAH CAIR TEMPE DENGAN METODE RUNGE KUTTA FEHLBERG
}

\author{
R. R.Maasawet ${ }^{1}$, A. I. Jaya ${ }^{2}$, dan R. Ratianingsih ${ }^{3}$ \\ 1,2,3 Program Studi Matematika Jurusan Matematika \\ Fakultas Matematika dan IImu Pengetahuan Alam Universitas Tadulako \\ Jalan Sukarno-Hatta Km. 9 Palu 94118, Indonesia \\ 1reginadwi14@gmail.com, 3ratianingsih@yahoo.com
}

\section{ABSTRACT}

This research studies the numerical solution of differential equations that represent a mathematical model of the biomassa and bacterial growth in the production of biogas from tempe wastewater. The numerical solution of the model is determind by runge kutta Fehlberg (RKF). RKF method, could be combined with maple mathematical software to minimize the resulting error rate. The method will give an iterative numerical solution as follow:

$$
\begin{aligned}
& x_{i+1}=x_{i}+\frac{25}{216} k_{1}+\frac{1408}{2565} k_{3}+\frac{2197}{4101} k_{4}-\frac{1}{5} k_{5} \\
& s_{i+1}=s_{i}+\frac{25}{216} m_{1}+\frac{1408}{2565} m_{3}+\frac{2197}{4101} m_{4}-\frac{1}{5} m_{5}
\end{aligned}
$$

The value of $k_{1}, k_{3}, k_{4}, k_{5}$ and $m_{1}, m_{3}, m_{4}, m_{5}$ are obtained by using the right hand side function of the differential equations system. The result shows that the number of biogas increases with respect to time and reaches the volume of $99,24 \%$. Bacteria will also increases with respect to time and achieves the growth of $11,47 \%$. This condition is no longer happened because of the death of bacteria. As a consequence, the number of biogas will not increase anymore.

Keywords : : Differential Equation, Differential Equation Firs Order, Numeric Solution Nonlinier.

\section{ABSTRAK}

Penelitian ini mengkaji solusi numerik sistem persamaan differensial yang mempresentasikan model matematika dari proses pertumbuhan biomassa dan bakteri pada proses pembuatan biogas dari limbah cair tempe dengan menggunakan metode runge kutta Fehlberg. Metode runge kutta Fehlberg atau RKF termasuk keluarga metode runge kutta yang dipakai untuk menetukan solusi numerik persamaan differensial nonlinier orde satu. Penggunaan metode RKF dapat dipadukan dengan aplikasi perangkat lunak maple untuk meminimalisir tingkat kesalahan yang dihasilkan. Dengan metoda tersebut solusi numerik yang diperoleh untuk sistem persamaan differensial pada setiap iterasinya yaitu : 


$$
\begin{aligned}
& x_{i+1}=x_{i}+\frac{25}{216} k_{1}+\frac{1408}{2565} k_{3}+\frac{2197}{4101} k_{4}-\frac{1}{5} k_{5} \\
& s_{i+1}=s_{i}+\frac{25}{216} m_{1}+\frac{1408}{2565} m_{3}+\frac{2197}{4101} m_{4}-\frac{1}{5} m_{5}
\end{aligned}
$$

Besarnya harga $k_{1}, k_{3}, k_{4}, k_{5}$ dan $m_{1}, m_{3}, m_{4}, m_{5}$ didapatkan dari fungsi yang terdapat pada ruas kanan. Hasil penelitian memperlihatkan bahwa biogas akan bertambah seiring dengan pertumbuhan waktu hingga mencapai $99,24 \%$. Bakteri juga bertambah seiring dengan waktu hingga mencapai pertumbuhan maksimal sebesar $11,47 \%$ untuk selanjutnya menurun karena kematian.Biogas tidak lagi bertambah setelah bakteri sudah mencapai pertumbuhan maksimal.

Kata Kunci : Persamaan differensial, Persamaan Differential Nonlinier, Solusi Numerik.

\section{PENDAHULUAN}

\subsection{Latar Belakang}

Sumber daya energi mempunyai peran penting dalam semua aspek pembangunan ekonominasional. Energi diperlukan untuk pertumbuhan kegiatan industri dan rumah tangga. Dalam jangka panjang, peran energi akan lebih berkembang untuk mendukung pertumbuhan sektor industri dan kegiatan lain yang terkait. Meskipun Indonesia adalah salah satu penghasil batu bara, minyak bumi dan gas, namun dengan berkurangnya cadangan minyak dan penghapus subsidi menyebabkan harga minyak naik dan kualitas lingkungan yang menurun akibat pengguna bahan bakar fosil yang berlebihan.

Biogas sebagai salah satu sumber energi yang dapat diperbaharui dan dapat menjawab akan kebutuhan energi sekaligus menyediakan kebutuhan hara tanah dari pupuk cair dan padat yang merupakan hasil sampingannya serta mengurangi efek rumah kaca. Pemanfaatan biogas sebagai sumber energi alternatif dapat mengurangi penggunaan kayu bakar. Dengan demikian dapat mengurangi usaha penebangan hutan, sehingga ekosistem hutan terjaga. Biogas menghasilkan api biru yang bersih dan tidak menghasilkan asap.

Energi biogas sangat potensial untuk dikembangkan karena produksi biogas peternakan ditunjang oleh kondisi yang kondusif dari dunia peternakan sapi di Indonesia saat ini. Disamping itu kenaikan tarif listrik, kenaikan minyak tanah, minyak solar dan minyak diesel telah mendorong pengembangan sumber energi alternatif yang murah, berkelanjutan dan ramah lingkungan.

Metode Runge Kutta adalah suatu metode persamaan differensial langkah satu yang dikembangkan oleh dua ahli yaitu Runge dan Kutta. Dalam menyelesaikan persamaan differensial berbentuk $\frac{d y}{d x}=f(x, y)$ membutuhkan turunan yang lebih tinggi untuk mencapai 
derajat ketelitian tepat, akan tetapi dalam metode Runge kutta ini, dalam mencapai derajat yang lebih tinggi tidak membutuhkan turunan yang kompleks.

Metode RKF tergolong dalam metode Runge Kutta 4, akan tetapi memiliki ketelitian sampai orde 5. Ketelitian yang tinggi ini dimungkinkan karena metode RKF memiliki 6 buah 'konstanta perhitungan antara' yang berperan untuk mengupdate solusi sampai orede 5 . Dengan kata lain, dapat dikatakan bahwa metode ini merupakan metode Runge Kutta yang saat ini paling populer. Pada metode ini galat pemotongannya dihitung dengan membandingkan hasil perhitungan $y_{i+1}$ dengan hasil perhitungan $y_{i+1}$ pada orde selanjutnya.

Pada proses pembuatan biogas limbah cair tempe dicampur dengan karkas sapi yang mengandung bakteri. Dalam prosesnya pertumbuhan bakteri tersebut membutuhkan limbah cair tempe sebagai bahan makanan (substrat). Pencampuran limbah cair tempe dengan karkas sapi mengakibatkan terjadinya fermentasi yang menghasilkan biogas. Model matematika yang mengamati pertumbuhan biomassa yang terbentuk dikaitkan dengan perubahan substrat. Model tersebut akan diselesaikan dengan cara numerik dengan metode RKF.

\subsection{Rumusan Masalah}

1. Bagaimana prediksi pertumbuhan biomassa dan bakteri dari waktu ke waktu dengan menggunakan metode Runge Kutta Felhberg?

2. Bagaimana interpretasi pertumbuhan biomassa dan bakteri berdasarkan plot greafik pada limbah cair tempe?

\subsection{Tujuan}

1. Untuk mendapatkan hasil prediksi pertumbuhan biomassa dan bakteri dari waktu ke waktu dengan menggunakan metode Runge Kutta Felhberg.

2. Untuk mendapatkan interpretasi pertumbuhan biomassa dan bakteri berdasarkan plot grafik pada limbah cair tempe.

\subsection{Manfaat Penelitian}

Adapun manfaat yang dapat diperoleh dari penelitian ini adalah sebagai berikut :

1. Dapat memprediksi perkiraan peningkatan biomassa dan bakteri dari limbah cair tempe dari waktu ke waktu dengan menggunakan metode Runge Kutta Fehlberg.

2. Untuk dijadikan sebagai bahan referensi dalam mengembangkan ilmu Matematika secara numerik khususnya melalui metode Runge Kutta Fehlberg. 


\subsection{Asumsi Penelitian}

Adapun asumsi yang digunakan dalam penelitian ini adalah:

1. Bersifat biodigestik dari proses anaerobik.

2. Metode Runge Kutta Fehlberg digunakan untuk menentukan solusi numerik dari model dinamik pertumbuhan biomassa dan bakteri pada limbah cair tempe.

\subsection{Ruang Lingkup Penelitian}

Penelitian ini mengkaji pertumbuhan biomassa dan bakteri yang direpresentasikan oleh model matematika yang dipengaruhi oleh nilai parameter $S_{t}$ (Konsentrasi bakteri pada saat $\mathrm{t}$.

\section{METODE PENELITIAN}

Penelitian dilakukan sesuai prosedur dibawah ini :
a. Memulai penelitian.
b. Kajian pustaka
c. Memilih model
d. Menerapkan RKF pada model
e. Simulasi solusi numerik pada model.
f. Menggambarkan kurva pertumbuhan biomassa dan bakteri
g. Menyimpulkan hasil penelitian.
h. Selesai.

\section{HASIL DAN PEMBAHASAN}

\subsection{Hasil penelitian}

3.1.1 Model Pertumbuhan Biomassa dan Bakteri Pada Proses Pembuatan Biogas Dari Limbah Cair Tempe

Penyelesaian sistema persamaan differensial yang mempresentasikan interaksi antara biomassa dan bakteri pada proses pembuatan biogas dari limbah cair tempe ditentukan secara numerik dengan metode Runge Kutta Fehlberg. Persamaan tersebut dinyatakan sebagai berikut :

$$
\begin{aligned}
& \frac{d X}{d t}=\left(\frac{0,65 S(t)}{\frac{1}{2}+2 S(t)+2 S(t)^{2}}-0,0001\right) X(t) \\
& \frac{d S}{d t}=\frac{0,65 S(t) X(t)}{\frac{1}{2}+2 S(t)+2 S(t)^{2}} \ldots \ldots \ldots \ldots \ldots \ldots \ldots \ldots \ldots \ldots \ldots \ldots \ldots \ldots \ldots
\end{aligned}
$$




\subsubsection{Menerapkan Metode Runge Kutta Fehlberg}

Solusi numerik dari model pada persamaan (1) dan (2) diperoleh dengan menerapkan metode Runge Kutta Fehlberg. Mengingat model tersebut merupakan sistem persamaan differensial orde satu, sehingga diperoleh sebagai berikut :

$x_{i+1}=x_{1}+\frac{25}{216} k_{1}+\frac{1408}{2565} k_{3}+\frac{2197}{4101} k_{4}-\frac{1}{5} k_{5}$

$s_{i+1}=s_{i}+\frac{25}{216} m_{1}+\frac{1408}{2565} m_{3}+\frac{2197}{4101} m_{4}-\frac{1}{5} m_{5}$

dengan :

$k_{1}=h . f\left(x_{i} s_{i}\right)$

$m_{1}=h \cdot g\left(x_{i} s_{i}\right)$

$k_{2}=h . f\left(x_{i}+\frac{1}{4} h, s_{i}+\frac{1}{4} k_{1}\right)$

$m_{2}=h \cdot g\left(x_{0}+\frac{1}{4} h, s_{0}+\frac{1}{4} m_{1}\right)$

$k_{3}=h . f\left(x_{i}+\frac{3}{8} h, s_{i}+\frac{3}{32} k_{1}+\frac{9}{32} k_{2}\right)$

$m_{3}=h \cdot g\left(x_{0}+\frac{3}{8} h, s_{0}+\frac{3}{32} m_{1}+\frac{9}{32} m_{2}\right)$

$k_{4}=h . f\left(x_{i}+\frac{12}{13} h, s_{i}+\frac{1932}{2197} k_{1}-\frac{7200}{2197} k_{2}+\frac{7296}{2197} k_{3}\right)$

$m_{4}=h \cdot g\left(x_{0}+\frac{12}{13} h, s_{0}+\frac{1923}{2197} m_{2}-\frac{7200}{2197} m_{2}+\frac{7296}{2197} m_{3}\right)$

$k_{5}=h . f\left(x_{i}+h, y_{i}+\frac{439}{216} k_{1}-8 k_{2}+\frac{3680}{513} k_{3}-\frac{845}{4104} k_{4}\right)$

$m_{5}=h \cdot g\left(x_{0}+h, s_{0}+\frac{439}{216} m_{1}-8 m_{2}+\frac{3680}{513} m_{3}-\frac{845}{4104} m_{4}\right)$

\subsubsection{Simulasi Solusi Numerik}

Perhitungan nilai $k_{1}, k_{2}, k_{3}, k_{4}, k_{5}$ dan $m_{1}, m_{2}, m_{3}, m_{4}, m_{5}$ diperoleh dari persamaan (5) sampai (14) sebagai berikut :

- $k_{1}=h . f\left(x_{0}, s_{0}\right)=h\left(\frac{0,65 s_{0}}{\frac{1}{2}+2\left(s_{0}\right)+2\left(s_{0}\right)^{2}}-0.0001\right) x_{0}=0$

- $m_{1}=h \cdot g\left(x_{0}, s_{0}\right)=h\left(\frac{0.65\left(s_{0}\right)\left(x_{0}\right)}{\frac{1}{2}+2(s)+2(s)^{2}}\right)=0$

- $k_{2}=h . f\left(x_{0}+\frac{1}{4} h, s_{0}+\frac{1}{4} k_{1}\right)=0.000024975$

- $m_{2}=h \cdot g\left(x_{0}+\frac{1}{4} h, s_{0}+\frac{1}{4} m_{1}\right)=0.0000025$

- $k_{3}=h . f\left(x_{0}+\frac{3}{8} h, s_{0}+\frac{3}{32} k_{1}+\frac{9}{32} k_{2}\right)=0.000005412904$

- $m_{3}=h \cdot g\left(x_{0}+\frac{3}{8} h, s_{0}+\frac{3}{32} m_{1}+\frac{9}{32} m_{2}\right)=0.00000541662$

- $k_{4}=h . f\left(x_{0}+\frac{12}{13} h, s_{0}+\frac{1923}{2197} k_{1}-\frac{7200}{2197} k_{2}+\frac{7296}{2197} k_{3}\right)=0.0000133244$

- $m_{4}=h . g\left(x_{0}+\frac{12}{13} h, s_{0}+\frac{1923}{2197} m_{1}-\frac{7200}{2197} m_{2}+\frac{7296}{2197} m_{3}\right)=0.0000001138458$

- $k_{5}=h . f\left(x_{0}+h, s_{0}+\frac{439}{216} k_{1}-8 k_{2}+\frac{3680}{513} k_{3}-\frac{845}{4104} k_{4}\right)=0.000014435$

- $m_{5}=h . g\left(x_{0}+h, s_{0}+\frac{439}{216} m_{1}-8 m_{2}+\frac{3680}{513} m_{3}-\frac{845}{4104} m_{4}\right)=0.00923$ 
Berdasarkan nilai $k_{1}, k_{2}, k_{3}, k_{4}, k_{5}$ dan $m_{1}, m_{2}, m_{3}, m_{4}, m_{5}$ telah didapat maka solusi numerik $x_{i+1}$ dan $s_{i+1}$ diperoleh melalui skema numerik sebagai berikut :

$x_{i+1}=x_{0}+\frac{25}{216} k_{1}+\frac{1408}{2565} k_{3}+\frac{2197}{4101} k_{4}-\frac{1}{5} k_{5} \ldots \ldots$
$s_{i+1}=s_{i}+\frac{25}{216} m_{1}+\frac{1408}{2565} m_{3}+\frac{2197}{4101} m_{4}-\frac{1}{5} m_{5}$

Banyaknya biogas yang terbentuk dan bakteri yang bertambah pada tiap-tiap iteras diperoleh dari persamaan (15) dan (16) sebagai berikut :

Untuk $i=0$

- $x_{1}=x_{0}+\frac{25}{216} k_{1}+\frac{1408}{2565} k_{3}+\frac{2197}{4101} k_{4}-\frac{1}{5} k_{5}=0.0000072223$

- $s_{1}=s_{0}+\frac{25}{216} m_{1}+\frac{1408}{2565} m_{3}+\frac{2197}{4101} m_{4}-\frac{1}{5} m_{5}=0.998184$

Untuk $i=1$

- $x_{2}=x_{1}+\frac{25}{216} k_{1}+\frac{1408}{2565} k_{3}+\frac{2197}{4101} k_{4}-\frac{1}{5} k_{5}=0.0000144446$

- $s_{2}=s_{1}+\frac{25}{216} m_{1}+\frac{1408}{2565} m_{3}+\frac{2197}{4101} m_{4}-\frac{1}{5} m_{5}=0.996341$

Untuk $i=2$

- $x_{3}=x_{2}+\frac{25}{216} k_{1}+\frac{1408}{2565} k_{3}+\frac{2197}{4101} k_{4}-\frac{1}{5} k_{5}=0.0000216669$

- $s_{3}=s_{2}+\frac{25}{216} m_{1}+\frac{1408}{2565} m_{3}+\frac{2197}{4101} m_{4}-\frac{1}{5} m_{5}=0.994498$

Untuk $i=3$

- $x_{4}=x_{3}+\frac{25}{216} k_{1}+\frac{1408}{2565} k_{3}+\frac{2197}{4101} k_{4}-\frac{1}{5} k_{5}=0.000009389$

- $s_{4}=s_{3}+\frac{25}{216} m_{1}+\frac{1408}{2565} m_{3}+\frac{2197}{4101} m_{4}-\frac{1}{5} m_{5}=0.992655$

Untuk $i=4$

- $x_{5}=x_{4}+\frac{25}{216} k_{1}+\frac{1408}{2565} k_{3}+\frac{2197}{4101} k_{4}-\frac{1}{5} k_{5}=0.0000081612$

- $s_{5}=s_{4}+\frac{25}{216} m_{1}+\frac{1408}{2565} m_{3}+\frac{2197}{4101} m_{4}-\frac{1}{5} m_{5}=0.990812$

Untuk $i=5$

- $x_{6}=x_{5}+\frac{25}{216} k_{1}+\frac{1408}{2565} k_{3}+\frac{2197}{4101} k_{4}-\frac{1}{5} k_{5}=0.00000803842$

- $s_{6}=s_{5}+\frac{25}{216} m_{1}+\frac{1408}{2565} m_{3}+\frac{2197}{4101} m_{4}-\frac{1}{5} m_{5}=0.988969$

Untuk $i=6$

- $x_{7}=x_{6}+\frac{25}{216} k_{1}+\frac{1408}{2565} k_{3}+\frac{2197}{4101} k_{4}-\frac{1}{5} k_{5}=0.000015261$

- $s_{7}=s_{6}+\frac{25}{216} m_{1}+\frac{1408}{2565} m_{3}+\frac{2197}{4101} m_{4}-\frac{1}{5} m_{5}=0.98713$

Untuk $i=7$

- $x_{8}=x_{7}+\frac{25}{216} k_{1}+\frac{1408}{2565} k_{3}+\frac{2197}{4101} k_{4}-\frac{1}{5} k_{5}=0.00002248$

- $s_{8}=s_{7}+\frac{25}{216} m_{1}+\frac{1408}{2565} m_{3}+\frac{2197}{4101} m_{4}-\frac{1}{5} m_{5}=0.985287$

Untuk $i=8$

- $x_{9}=x_{8}+\frac{25}{216} k_{1}+\frac{1408}{2565} k_{3}+\frac{2197}{4101} k_{4}-\frac{1}{5} k_{5}=0.0000297$

- $s_{9}=s_{8}+\frac{25}{216} m_{1}+\frac{1408}{2565} m_{3}+\frac{2197}{4101} m_{4}-\frac{1}{5} m_{5}=0.98344$

Untuk $i=9$

- $x_{10}=x_{9}+\frac{25}{216} k_{1}+\frac{1408}{2565} k_{3}+\frac{2197}{4101} k_{4}-\frac{1}{5} k_{5}=0.0000102$

- $s_{10}=s_{9}+\frac{25}{216} m_{1}+\frac{1408}{2565} m_{3}+\frac{2197}{4101} m_{4}-\frac{1}{5} m_{5}=0.981597$ 


\subsubsection{Menggambarkan Kurva Pertumbuhan Biomassa dan Bakteri}

Solusi numerik yang diperoleh pada sesi 3.1.3 dilanjutkan sampai iterasi ke550 sehingga diperoleh kurva pertumbuhan biogas dan pertumbuhan bakteri sebagai berikut :

Tabel 1. Pertumbuhan Biomassa dan Bakteri.

\begin{tabular}{|c|c|c|c|c|c|}
\hline $\mathbf{t}$ & $\mathbf{x}$ & $\mathbf{s}$ & $\mathbf{t}$ & $\mathbf{x}$ & $\mathbf{s}$ \\
& (Biomassa) & (Bakteri) & & (Biomassa) & (Bakteri) \\
\hline 0.01 & 0.001444835 & 1.000278413 & 0.24 & 0.035460275 & 1.00689011 \\
\hline 0.02 & 0.002892457 & 1.0005575644 & 0.25 & 0.036974068 & 1.007186843 \\
\hline 0.03 & 0.004342872 & 1.00083746 & 0.26 & 0.03849083 & 1.007484369 \\
\hline 0.04 & 0.005796088 & 1.0011181 & 0.27 & 0.04001057 & 1.00778269 \\
\hline 0.05 & 0.007252114 & 1.00139947 & 0.5 & 0.075804918 & 1.01486759 \\
\hline 0.06 & 0.007252114 & 1.0016816 & 0.7 & 0.108291955 & 1.021389587 \\
\hline 0.07 & 0.010172619 & 1.0019645 & 0.8 & 0.125033099 & 1.0247816 \\
\hline 0.08 & 0.011637115 & 1.0022481 & 0.85 & 0.133531914 & 1.02651061 \\
\hline 0.09 & 0.013104449 & 1.00253248 & 0.95 & 0.150791609 & 1.03003725 \\
\hline 0.1 & 0.01457463 & 1.002817614 & 1 & 0.159544747 & 1.031834376 \\
\hline 0.11 & 0.016047664 & 1.003103508 & 1.5 & 0.252344677 & 1.051051856 \\
\hline 0.12 & 0.017523559 & 1.0033902 & 1.8 & 0.312819894 & 1.06359546 \\
\hline 0.13 & 0.019002324 & 1.00367758 & 1.9 & 0.333825917 & 1.067911204 \\
\hline 0.14 & 0.020483964 & 1.0039658 & 1.95 & 0.344491411 & 1.07008832 \\
\hline 0.15 & 0.021968489 & 1.004255 & 2 & 0.35526599 & 1.07227574 \\
\hline 0.16 & 0.023455906 & 1.00454443 & 2.2 & 0.39946212 & 1.081079404 \\
\hline 0.17 & 0.024946223 & 1.004835 & 2.4 & 0.445414916 & 1.089812401 \\
\hline 0.18 & 0.026439446 & 1.0051262 & 2.6 & 0.493082522 & 1.0981713589 \\
\hline 0.19 & 0.027935585 & 1.00542 & 2.8 & 0.542345794 & 1.10568821 \\
\hline 0.2 & 0.029434646 & 1.00571 & 3 & 0.592972199 & 1.111669603 \\
\hline 0.21 & 0.030936638 & 1.006005 & 3.4 & 0.696470483 & 1.1146584237 \\
\hline 0.22 & 0.032441568 & 1.006299 & 5 & 0.9762896 & 0.90949035 \\
\hline 0.23 & 0.033949445 & 1.0065941601 & 5.5 & 0.99240953 & 0.872568 \\
\hline & & & & & \\
\hline
\end{tabular}




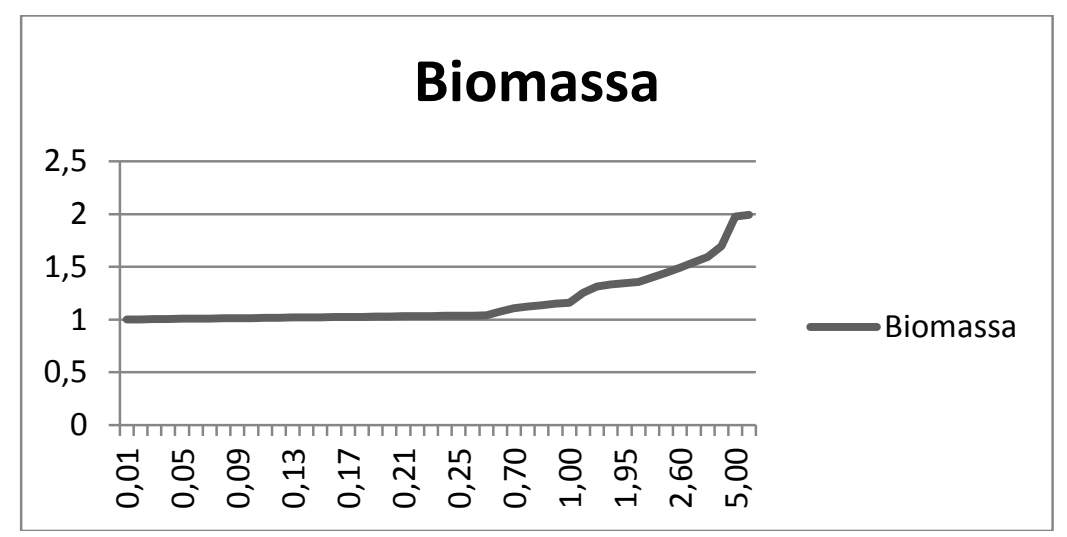

Gambar 1. Pertumbuhan Biomassa $(\mathrm{x})$ terhadap waktu $(\mathrm{t})$

Dari gambar 1 diperlihatkan bahwa prtumbuhan biomassa akan terus bertambah hingga mencapai produksi biogas maksimal.

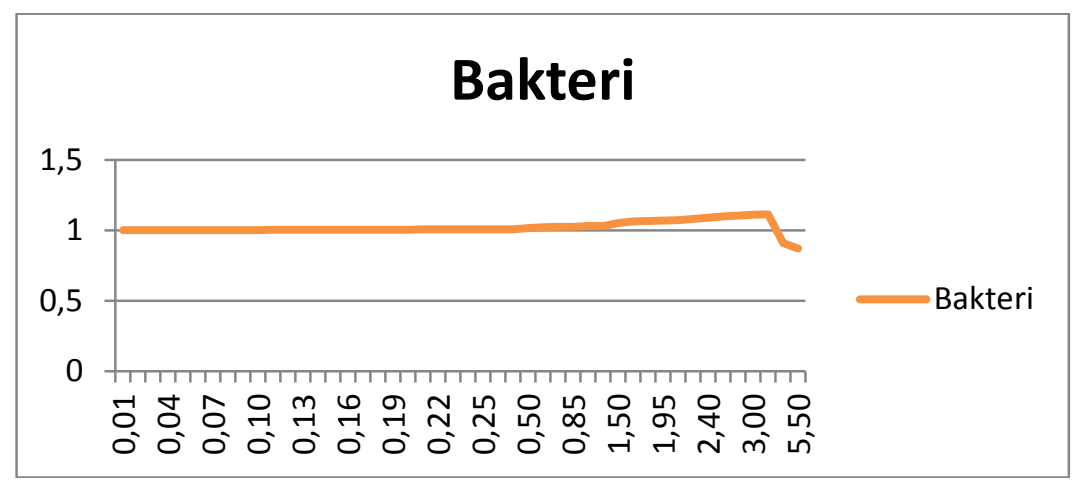

Gambar 2. Pertumbuhan Bakteri (s) terhadap waktu (t)

Dari gambar 2 diperlihatkan bahwa prtumbuhan biomassa akan terus bertambah hingga mencapai produksi biogas maksimal. Setelah itu bakteri tidak mengalami pertumbuhan lagi karena sudah mencapai usia maksimal hidupnya. Selain itu dalam penelitian ini tidak dilakukan pertambahan substrat pada proses pembuatan biogas. 


\subsection{Pembahasan}

Hasil penelitian pada sesi 3.1 memperlihatkan biogas yang akan bertambah seiring dengan pertumbuhan waktu hingga mencapai 99,24\% . Bakteri juga bertambah seiring dengan waktu hingga mencapai pertumbuhan maksimal sebesar $11,47 \%$ untuk selanjutnya menurun karena kematian. Biogas tidak lagi bertambah setelah bakteri sudah mencapai pertumbuhan maksimal.

\section{Kesimpulan}

Dari hasil penelitian dan pembahasan di atas disimpulkan sebagai berikut:

1. Secara umum solusi numerik sistem persamaan differensial yang mempresentasikan prediksi pertumbuhan biomassa dan bakteri dengan menggunakan metoda Runge Kutta fehlberg pada setiap iterasinya berbentuk :

$$
\begin{gathered}
x_{i+1}=x_{i}+\frac{25}{216} k_{1}+\frac{1408}{2565} k_{3}+\frac{2197}{4101} k_{4}-\frac{1}{5} k_{5} \\
s_{i+1}=s_{i}+\frac{25}{216} m_{1}+\frac{1408}{2565} m_{3}+\frac{2197}{4101} m_{4}-\frac{1}{5} m_{5}
\end{gathered}
$$

Dengan:

- $\quad k_{1}=h \cdot f\left(x_{0}, s_{0}\right)=h\left(\frac{0,65 s_{0}}{\frac{1}{2}+2\left(s_{0}\right)+2\left(s_{0}\right)^{2}}-0,0001\right) x$

- $\quad m_{1}=h \cdot g\left(x_{0}, s_{0}\right)=h\left(\frac{0,65\left(s_{0}\right)\left(x_{0}\right)}{\frac{1}{2}+2\left(s_{0}\right)+2\left(s_{0}\right)^{2}}\right)$

- $\quad k_{2}=h . f\left(x_{0}+\frac{1}{4} h, s_{0}+\frac{1}{4} k_{1}\right)$

- $\quad m_{2}=h \cdot g\left(x_{0}+\frac{1}{4} h, s_{0}+\frac{1}{4} m_{1}\right)$

- $\quad k_{3}=h . f\left(x_{0}+\frac{3}{8} h, s_{0}+\frac{3}{32} k_{1}+\frac{9}{32} k_{2}\right)$

- $\quad m_{3}=h \cdot g\left(x_{0}+\frac{3}{8} h, s_{0}+\frac{3}{32} m_{1}+\frac{9}{32} m_{2}\right)$

- $\quad k_{4}=h . f\left(x_{0}+\frac{12}{13} h, s_{0}+\frac{1923}{2197} k_{1}-\frac{7200}{2197} k_{2}+\frac{7296}{2197} k_{3}\right)$

- $\quad m_{4}=h . g\left(x_{0}+\frac{12}{13} h, s_{0}+\frac{1923}{2197} m_{1}-\frac{7200}{2197} m_{2}+\frac{7296}{2197} m_{3}\right)$

- $\quad k_{5}=h . f\left(x_{0}+h, s_{0}+\frac{439}{216} k_{1}-8 k_{2}+\frac{3680}{513} k_{3}-\frac{845}{4104} k_{4}\right)$

- $\quad m_{5}=h . g\left(x_{0}+h, s_{0}+\frac{439}{216} m_{1}-8 m_{2}+\frac{3680}{513} m_{3}-\frac{845}{4104} m_{4}\right)$

2. Hasil penelitian pada sesi 3.1 memperlihatkan biogas yang akan bertambah seiring dengan pertumbuhan waktu. Bakteri juga bertambah seiring dengan waktu hingga mencapai pertumbuhan maksimal untuk selanjutnya menurun karena kematian. Pertumbuhan biogas maksimal tercapai pada saat bakteri sudah mencapai pertumbuhan maksimal. 


\section{DAFTAR PUSTAKA}

[1]. Chapra, J, Steven ,1991, Metode Numerik Teknik, Universitas Indonesia: Jakarta

[2]. Ratianingsih, R., dkk, Prosiding Seminar Nasional Matematika Fakultas MIPA, Universitas Tadulako.

[3]. Srisertpol, J., Srinakorn, P., Kheawnak, A. and Chamniprasart, K. 2010, Mathematical Modeling and Parameters estimationof an Anaerobic Digestion of Shrimp of Culture Pond Sediment in a Biogas Process International Journal of Energy and Environment. Vol. 4. Issue 4: 213-220.

[4]. Ratih Ayuninghemi, 2009, Penyelesaian Persamaan Differensial Dengan Metode Adams Bashforth Menggunakan Matlab. Jurnal IImiah Tekhnologi dan Informasi ASIA, 2 ,3 dan 4. 